\title{
Genetic integrity of the human $Y$ chromosome exposed to groundwater arsenic
}

\author{
Safdar Ali, Sher Ali
}

\begin{abstract}
Background: Arsenic is a known human carcinogen reported to cause chromosomal deletions and genetic anomalies in cultured cells. The vast human population inhabiting the Ganges delta in West Bengal, India and Bangladesh is exposed to critical levels of arsenic present in the groundwater. The genetic and physiological mechanism of arsenic toxicity in the human body is yet to be fully established. In addition, lack of animal models has made work on this line even more challenging.

Methods: Human male blood samples were collected with their informed consent from 5 districts in West Bengal having groundwater arsenic level more than $50 \mu \mathrm{g} / \mathrm{L}$. Isolation of genomic DNA and preparation of metaphase chromosomes was done using standard protocols. End point PCR was performed for established sequence tagged sites to ascertain the status of recombination events. Single nucleotide variants of candidate genes and amplicons were carried out using appropriate restriction enzymes. The copy number of DYZ1 array per haploid genome was calculated using real time PCR and its chromosomal localization was done by fluorescence in-situ hybridization (FISH).

Results: We studied effects of arsenic exposure on the human $Y$ chromosome in males from different areas of West Bengal focusing on known recombination events (P5-P1 proximal; P5-P1 distal; gr/gr; TSPY-TSPY, b1/b3 and b2/b3), single nucleotide variants (SNVs) of a few candidate Y-linked genes (DAZ, TTY4, BPY2, GOLGA2LY) and the amplicons of AZFC region. Also, possible chromosomal reorganization of DYZ1 repeat arrays was analyzed. Barring a few microdeletions, no major changes were detected in blood DNA samples. SNV analysis showed a difference in some alleles. Similarly, DYZ1 arrays signals detected by FISH were found to be affected in some males.

Conclusions: Our $Y$ chromosome analysis suggests that the same is protected from the effects of arsenic by some unknown mechanisms maintaining its structural and functional integrities. Thus, arsenic effects on the human body seem to be different compared to that on the cultured cells.
\end{abstract}

\section{Background}

Several heavy metals are present in the environment all over the world in amounts alarmingly unsafe for the human population of which chromium and arsenic are good examples. These metals affect human systems in various ways but their possible genetic consequences remain unknown. In the context of arsenic, Ganges delta in West Bengal, India and Bangladesh, both areaand population wise are the worlds most affected regions. In Bangladesh, over $60 \%$ of villages are at the risk from arsenic exposure [1].

\footnotetext{
* Correspondence: alisher@nii.res.in

Molecular Genetics Laboratory, National Institute of Immunology, Aruna Asaf Ali Marg, New Delhi-110067, India
}

Full list of author information is available at the end of the article
Arsenic in the environment exists naturally in two forms; as arsenite (trivalent $\mathrm{As}^{3+}$ ) or arsenate (pentavalent $\left.\mathrm{As}^{5+}\right)$. Humans are exposed to arsenic by ingestion of contaminated water, food and drugs or inhalation from burning of arsenic contaminated coal. Inhalation is also contributed by semiconductor and glass manufacturing sites. Arsenic is present in small to trace amounts in rocks, sediments and all natural water resources which includes rivers, sea water and groundwater. In the absence of treatment process, high levels of arsenic become a major health hazards. The World Health Organization (WHO) recommends less than $10 \mu \mathrm{g} / \mathrm{L}$ arsenic in drinking water and its maximum permissible limit is $50 \mu \mathrm{g} / \mathrm{L}$ [2]. Our present understanding of the metal demands the limit to be set at $10 \mu \mathrm{g} / \mathrm{L}$ but the

\section{() Biomed Central}


lack of adequate testing facilities at such low concentrations in countries with this problem makes them adhere to a high permissible limit. The sensitivity of the scenario may be judged by the fact that at consumption of a liter of water per day with $50 \mu \mathrm{g} / \mathrm{L}$ arsenic, 13 per thousand individuals may die due to liver, lung, kidney or bladder cancer [3]. The risk is only reduced to about 37 per 10000 individuals at a level of $10 \mu \mathrm{g} / \mathrm{L}$ which is the lowest of the enacted guidelines across the world [4]. Besides, lesser exposed males are apparently more prone to developing skin lesions as compared to females with far greater exposure. Interestingly both sexes were maximally affected at the same age group of 35-44 years [5].

Arsenite despite being an established human carcinogen, its mechanism of carcinogenesis and genetic effects remain unclear. What is known is that it induces chromosomal aberrations in both human and rodent cell lines and the cells of exposed humans [6-9]. Subsequently, these genetic abnormalities become cause of cancer [10] though their random nature remains to be explained. In addition, its role as a tumor promoter [11] has been suggested without any direct evidence. Another possibility includes its action as a co-mutagen by interfering with DNA repair mechanism, enhancing the effect of mutagens like UV and MNU (N-methyl-N-nitrosourea) [12]. The greatest challenge in understanding arsenic carcinogenicity and its role in-vivo has been the absence of animal models since it fails to replicate its effect in rodents [13]. In addition the complexities seem to be increasing from risk of erectile dysfunction in exposed males [14] to its high levels in milk of lactating mothers [15]. Also, estrogen sensitive targets may be responsible for the differential affect in males and females [16]. Most affected regions in India are the 9 districts in West Bengal where the recorded groundwater arsenic level is more than $50 \mu \mathrm{g} / \mathrm{L}$ to which over 40 million people are exposed [17]. We collected human blood samples from these districts and analyzed them for anomalies, if any, focusing on their Y chromosomes.

\section{Methods}

Collection of blood samples and genomic DNA isolation Blood samples $(10 \mathrm{ml})$ were collected with informed consent from 98 males from different areas of West Bengal strictly in accordance with the Guidelines of Institutes Ethical and Bio-safety Committee. The regions were selected for having ground water arsenic of more than $50 \mu \mathrm{g} / \mathrm{L}$ as reported earlier [17]. Present study includes samples from 5 districts which include Kolkata, Mednipur, Murshidabad, Maldah and 24 Paragnas (S). The samples in the age group of 7 to 62 years were short listed by confirming that they were consuming ground water as such, without any treatment and were exposed to arsenic for a minimum period of 7 years. From these, 4 individuals $(2 \mathrm{k} 10,2 \mathrm{k} 28,2 \mathrm{k} 66$ and MC7) had skin lesions on faces or hands due to arsenic exposure. Two persons (2k11 and $2 \mathrm{k} 29)$ had been operated for prostate enlargement. Also, routine blood analysis for cell counts and hemoglobin level was done and only the ones found to be normal were included in the study. In addition blood was collected from 80 males residing in New Delhi without any arsenic exposure and used as controls. Genomic DNA isolation was done from blood using standard protocols [18].

\section{Sequence-tagged site PCR amplification}

STS spanning all the known regions of Y chromosome showing recombination deletions were amplified using end point PCR. These included P5-proximal P1, P5- distal P1, gr/gr, b1/b3 and b2/b3 deletion. Screening was done for deletion of entire AZFa or AZFc region. Recombination events known to occur in AZFa due to the presence of provirus $A$ and $B$ sequences were checked. The AZFb region was analyzed for its intactness using STS markers.

\section{End point PCR analysis}

The reactions in $20 \mu \mathrm{l}$ volume were carried out using Go Taq polymerase and $5 \times$ reaction buffer (Promega, Madison, USA), $200 \mu \mathrm{M}$ dNTPs and $100 \mathrm{ng}$ of template DNA. The reaction was conducted for 30 cycles, each involving denaturation at $95^{\circ} \mathrm{C}$ for 1 minute, annealing at $60^{\circ} \mathrm{C}$ for 1 minute and extension at $72^{\circ} \mathrm{C}$ for 1 minute besides initial denaturation at $95^{\circ} \mathrm{C}$ for 5 minutes and final extension at $72^{\circ} \mathrm{C}$ for 10 minutes. The amplified products were resolved on appropriate agarose gels. $\beta$ actin and SRY primers were used as positive controls [19].

\section{Single Nucleotide Variants (SNV) analysis}

For the analysis of SNVs initial PCR amplification was carried out as above in $50 \mu \mathrm{l}$ reaction mixture. After subsequent confirmation of amplification, PCR product was purified by adding $5 \mu \mathrm{l}$ of $3 \mathrm{M}$ sodium acetate and $150 \mu \mathrm{l}$ of absolute ethanol which was then incubated at $-70^{\circ} \mathrm{C}$ for 2 hours. Thereafter, it was pelleted $(13 \mathrm{k} \mathrm{rpm}$ for 20 minutes) and washed with $70 \%$ ethanol before dissolving and putting up for digestion with appropriate restriction enzymes.

\section{Real time PCR analysis of DYZ1 region}

Genomic DNA from different samples was used as template for analysis of number of DYZ1 arrays using Real Time PCR. Power SYBR ${ }^{\bullet}$ green (Part No. 4367659) from Applied Biosystems (ABI, USA). Reactions were carried out on Sequence Detection System 7500 (ABI, USA). Ten fold serial dilutions of the cloned DYZ1 plasmid 
was made starting with 30 crore copies and used for standard curve preparation. The genomic DNA was used in 3 different concentrations $2 \mathrm{ng}, 1 \mathrm{ng}$ and 0.5 ng and subsequently copies were calculated per genome for each sample. All the reactions were carried out in triplicates. All the standard curves used had a slope value of 3.3-3.5 and $R^{2}$ value of $>0.99$.

\section{Fluorescence in situ hybridization (FISH)}

Approximately, $300 \mu \mathrm{l}$ of freshly collected blood from both set of samples was cultured in PB Max karyotyping medium (GIBCO) and chromosome preparation was done using standard protocols [20]. A $3.4 \mathrm{~Kb}$ clone of the DYZ1 was labeled with biotin-dUTP using Nick Translation Kit from Vysis (IL, USA) and used for FISH following standard protocols [20]. The images were analyzed by Applied Imaging Systems Cytovision software version 3.92 .

\section{Results}

Overall STS analysis for recombination events and chromosome intactness

Samples were checked for the presence of STSs encompassing recombination events and intactness of the azoospermia factor (AZF) regions.

\section{AZFc region}

The AZFc region was analyzed for its intactness and occurrence of different recombination events (P5-P1 proximal; P5-P1 distal; gr/gr; b1/b3 and b2/b3) as per the details given in table 1[21-30]. Besides, the TSPYTSPY recombination was also accounted for (sY1240, sY1250 positive and sY276, sY1238, sY637, sY1319 all negative). None of the samples showed any of these described recombination events. However, there were random microdeletions in some samples. Results on STS mapping of representative samples are shown in figure 1.

\section{AZFa region}

The presence of AZFa region was ascertained by standard STS mapping involving six STSs sY78, sY1251, sY1317, sY1316, sY1234 and sY1231. The absence of sY1317, sY1316, and sY1234 has been taken to be indicative of AZFa deletion. We did not find absence of any of these STSs instead all of them were intact (Figure 1). Further, the region having HERV provirus sequences was checked for homologous recombination following standard markers [27] and the results are given in Figure 2. No sample had the characteristic provirus A or B mediated recombination. However, several microdeletions mostly confined to the provirus $B$ region were detected.

\section{AZFb region}

The AZFb region was analyzed by multiplex PCR using standard protocol [26]. It involved the screening of 10

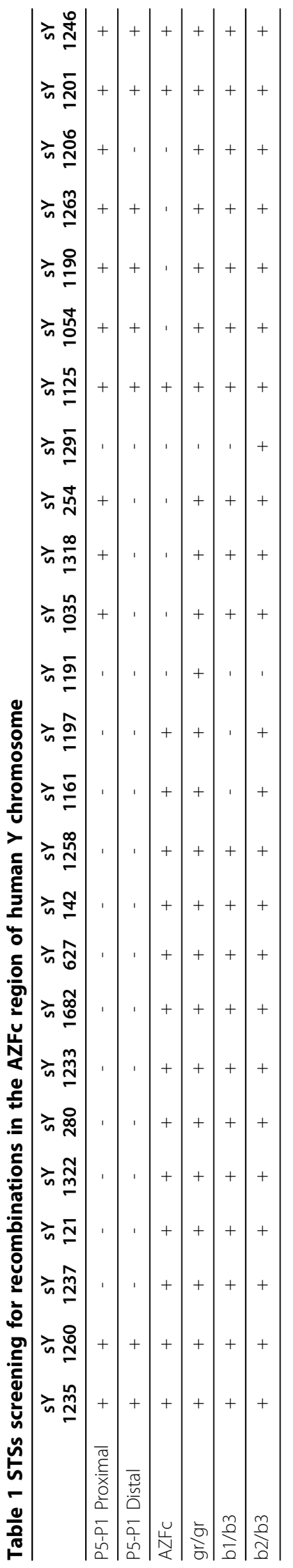




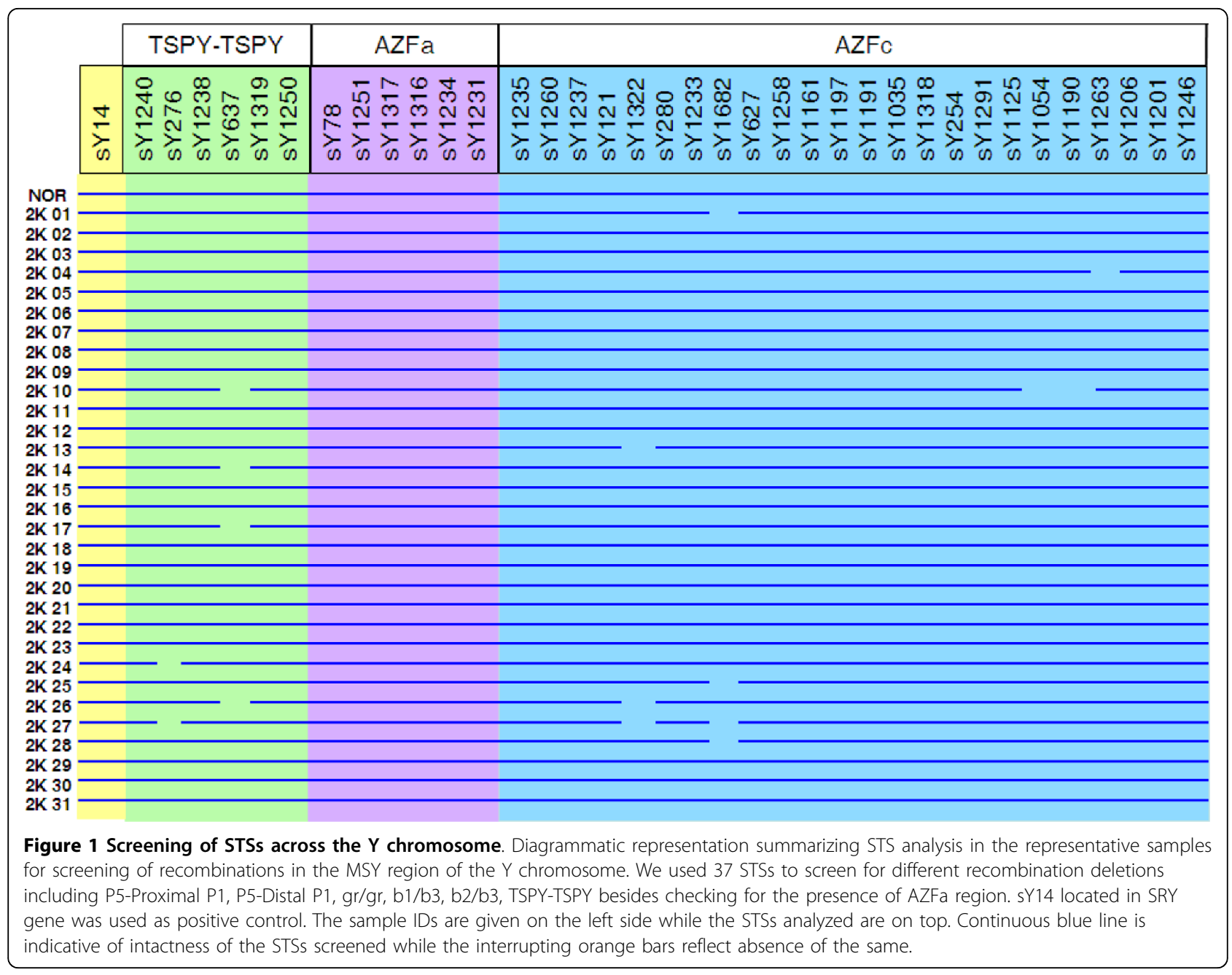

STSs including sY86, DFFRY, DDX3Y, sY95, sY117, sY125, sY127, sY254, sY255 and RBMY STSs (Accession no. G73375). All the samples were found to be positive for these STSs (see figure 3a-c) indicating the intactness of $\mathrm{AZFb}$ region.

\section{SNV/SFV analysis}

After the recombination analysis, we ascertained the intactness of gene copies and amplicons by single nucleotide variants (SNVs) in the AZFc region. We analyzed 7SNVs in DAZ gene, one each in BPY2, TTY4 and GOLGA2LY genes and 7 located in different amplicons (b2, b3, b4, g1, g2, g3 and Gr)

\section{$D A Z S N V s$}

The samples were analyzed for reported SNVs in DAZ gene which included DAZ SNV I to VI [31] and sY581 [32]. The amplicons were studied by end point PCR amplification followed by digestion by corresponding restriction enzymes (table 2). The DAZ deletions were ascertained following standard method [28] that showed intactness of the copies of DAZ gene. One sample $2 \mathrm{k} 44$ showed deletion in the DAZ4 gene (DAZ del. haplotype 4).

\section{Amplicons}

Further, we checked the SNVs in the blue, green and $\mathrm{Gr}$ amplicons in the AZFc region following standard protocol [33] to establish their correlations with the normal functioning of the $\mathrm{Y}$ chromosome. Representative gel pictures for the same are shown in figure $3 \mathrm{~d}-\mathrm{g}$. The details of expected fragment pattern are given in table 2 and results summarized in table 3 and figure 4 .

\section{Other AZFc genes}

We analyzed the SNV variants of BPY2, TTY4 and GOLGA2LY genes on the Y chromosome. Few samples showed allelic variations (Figure $3 \mathrm{~h}-\mathrm{i}$ ) which have been summarized in table 4 .

\section{DYZ1 array}

The DYZ1 repeats on the human Y chromosome have long been contemplated for their transcriptional status 


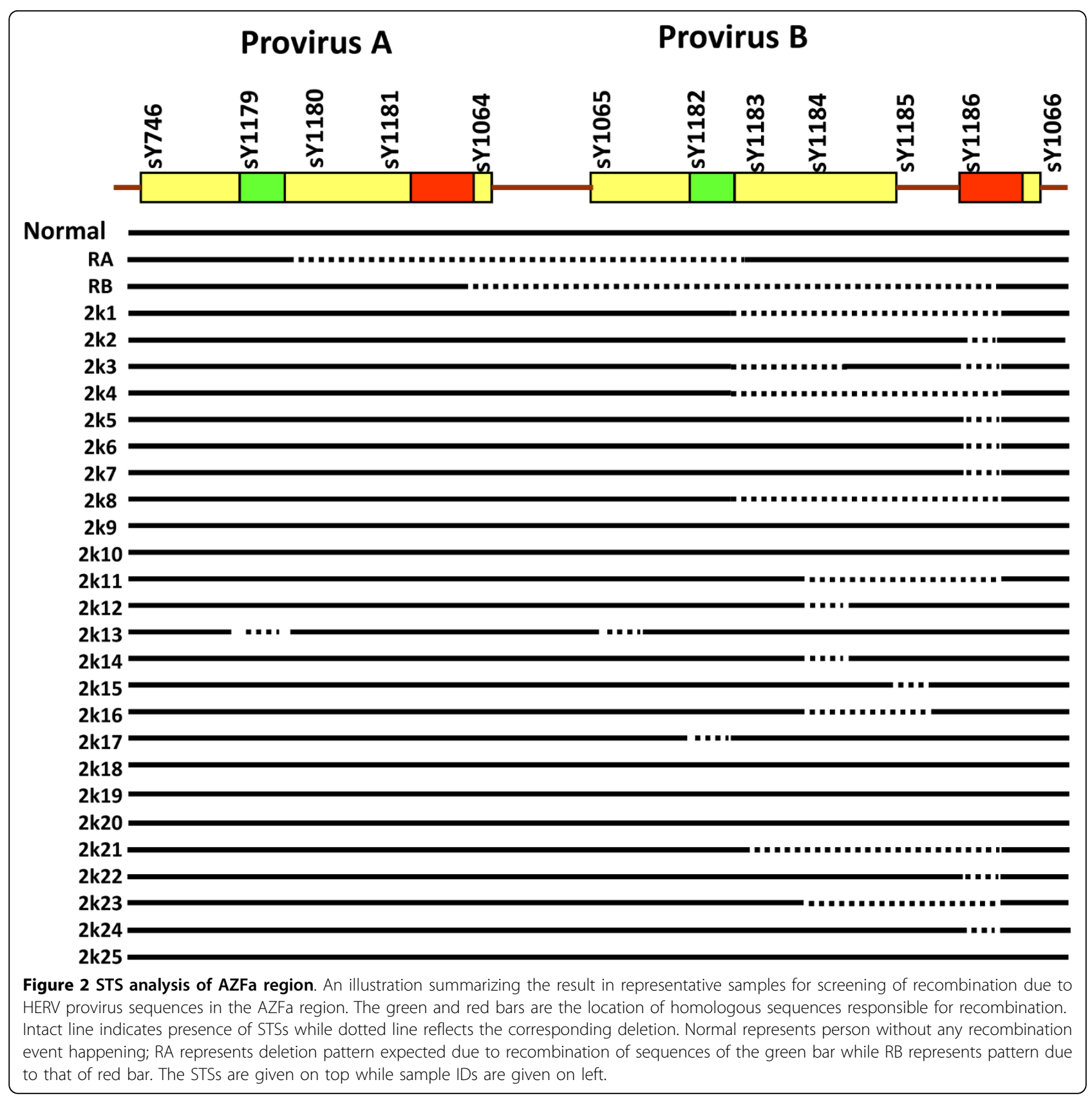

and possible involvement in the chromosome stability $[34,35]$. We studied its overall intactness and copy number variation in the exposed males.

Intactness by end point PCR

For studying DYZ1 intactness, we designed 4 sets of primers spanning the entire $3.4 \mathrm{~kb}$ array. These primers were then used in 10 different combinations for end point PCR amplification. The details of the primers used, their locations, different combinations and expected amplicons are shown in tables 5 and 6. As per this analysis all the samples (normal and exposed) showed an intact DYZ1 array. The representative pictures related to this analysis are shown in figure 5 .

Assessment of Copy number variation of DYZ1 by real time PCR

We checked number of DYZ1 copies per genome on real time PCR using SYBR green chemistry. Cloned DYZ1 array was used to prepare standard curve by tenfold serial dilutions starting from 30 crore to 300 copies. The copies per genome in samples were subsequently extrapolated from the standard curve. A representative standard curve along with its amplification plots and 


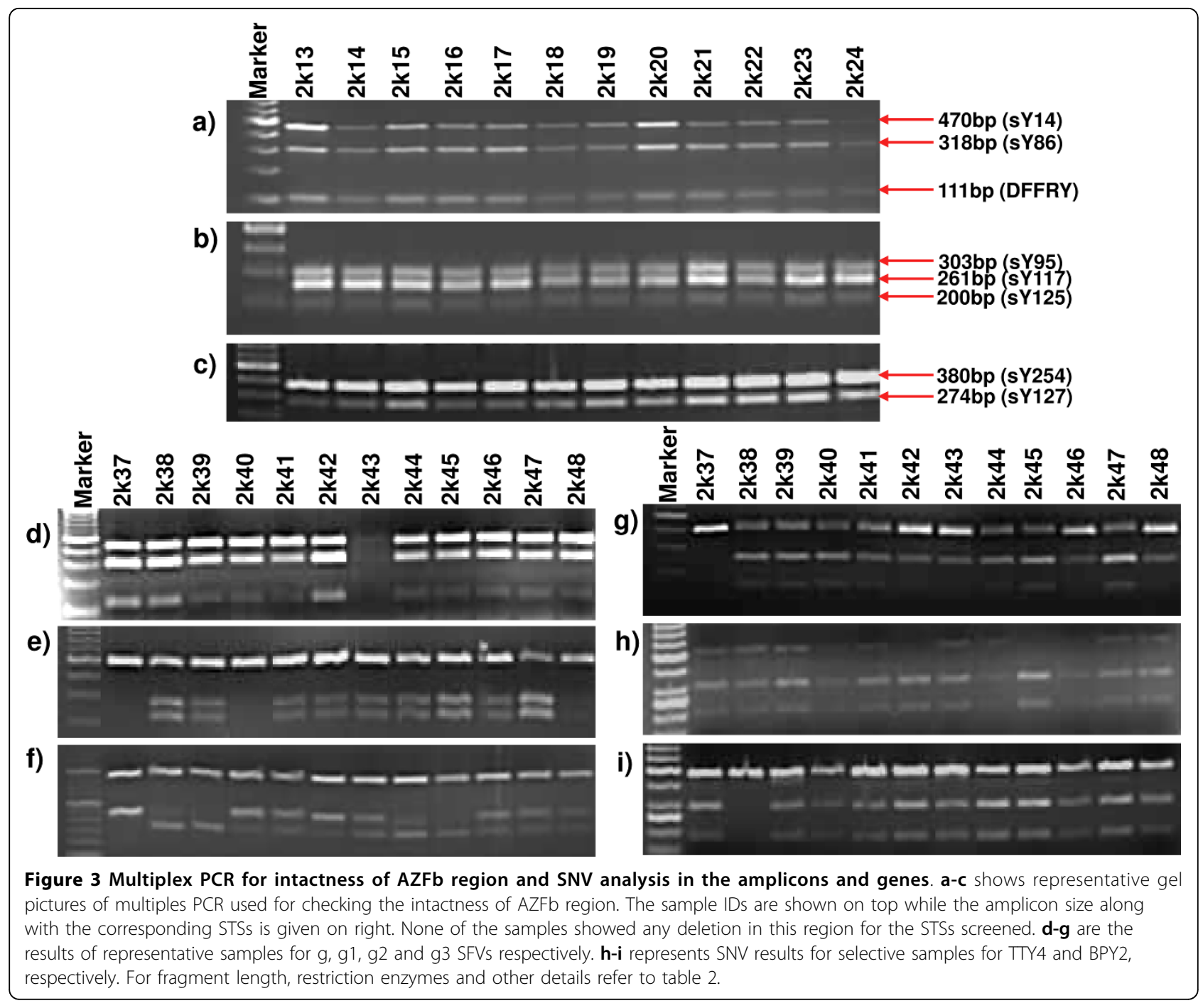

dissociation curve has been shown in figure 6a-c. The samples from arsenic exposed areas showed a very high degree of copy number variation ranging from 672 (sample 2k48) to 8576 (sample 2k21). Variation in the unexposed samples was found to be within a lower 3910 to 4200 range. The distribution of variations in copy number across the samples has been summarized in figure $6 \mathrm{~d}$.

\section{FISH analysis}

We used the $3.4 \mathrm{~kb}$ clone of DYZ1 array as FISH probe for its chromosomal localization. The signals showed two significant aspects. First, a consistent variation was found in the signal intensity amongst nuclei of the same individual. Secondly, in 19 exposed samples about (20$25 \%)$ cells showed no signal. The remaining individuals had signals in $>98 \%$ cells. To rule out experimental error, a positive control (individual already tested for consistent signals) was used with the same probe preparation. The experiment was replicated several times and each time around 400 nuclei was screened. Representative captured images of one of the samples are shown in figure 7 highlighting these observations. All the cells in the normal control samples showed consistent DYZ1 signals. Also, to ascertain the presence of Y chromosome, WCP-Y spectrum green (Cat no. 32122024) was purchased from VYSIS (Illinois, USA) and used as reported earlier [36]. It showed signals in $>96 \%$ nuclei of all the individuals. Analysis of nuclei with specific probes for different regions of DYZ1 array is underway.

\section{Discussion}

Arsenic is a known source of human carcinogen though the mechanism of its carcinogenesis is still not clear. The metabolism of arsenic involves methylation steps subsequent to which monomethylarsanous acid (MMA) 
Table 2 The details of SNVs analyzed in the study

\begin{tabular}{|c|c|c|c|c|c|c|}
\hline Target & SNV & Primers & Enzyme & Fragments & Allele & Present in copies \\
\hline \multirow[t]{14}{*}{ DAZ Genes SNVs } & 1 & SA770 & Fsp I & 709 & A & $1,2,3$ \\
\hline & & SA771 & & $398+311$ & $\mathrm{~B}$ & 4 \\
\hline & ॥ (sY586) & SA446 & Mbo I & 182 & A & 1 \\
\hline & & SA447 & & $122+60$ & $\mathrm{~B}$ & $2,3,4$ \\
\hline & III & SA772 & Taq 1 & 301 & A & 2 \\
\hline & & SA773 & & $184+117$ & $\mathrm{~B}$ & $1,3,4$ \\
\hline & IV & SA774 & Alu I & 630 & $A$ & 2 \\
\hline & & SA775 & & $398+262$ & $\mathrm{~B}$ & $1,3,4$ \\
\hline & $V(s Y 587)$ & SA444 & Dral & $195+49$ & A & 3,4 \\
\hline & & SA445 & & $122+73+49$ & $\mathrm{~B}$ & 1,2 \\
\hline & $\mathrm{Vl}$ & SA776 & Afl III & 431 & A & $1,2,3$ \\
\hline & & SA777 & & $248+183$ & B & 4 \\
\hline & sY581 & SA442 & Sau3a & $189+63$ & $A$ & 1,4 \\
\hline & & SA443 & & $130+63+59$ & $\mathrm{~B}$ & 2,3 \\
\hline \multirow[t]{6}{*}{ Blue Amplicons } & b2_AZFc_SFV & SA1237 & Mnll & 653 & A & b1, b3, b4 \\
\hline & & SA1238 & & $452+197$ & B & b2 \\
\hline & b3_AZFC_SFV & SA1239 & XmaJl & 510 & $A$ & b1, b2, b4 \\
\hline & & SA1240 & & $261+249$ & B & b3 \\
\hline & b4_AZFC_SFV & SA1241 & Hphl & 630 & $A$ & b1, b2, b3 \\
\hline & & SA1242 & & $347+282$ & B & b4 \\
\hline \multirow[t]{6}{*}{ Green Amplicons } & g1_AZFC_SFV & SA1243 & Alw261 & 500 & A & $g 2, g 3$ \\
\hline & & SA1244 & & $272+224$ & B & g1 \\
\hline & g2_AZFC_SFV & SA1245 & $\mathrm{NmuCl}$ & $274+180+38$ & $A$ & g2 \\
\hline & & SA1246 & & $274+137+38+28$ & $\mathrm{~B}$ & $g 1, g 3$ \\
\hline & g3_AZFC_SFV & SA1247 & Alw261 & 400 & $A$ & g3 \\
\hline & & SA1248 & & $251+163$ & B & $g 1, g 2$ \\
\hline \multirow[t]{2}{*}{ Gr Amplicons } & g_AZFC_SFV & SA1249 & Eco1051 & 440 & A & Gr1 \\
\hline & & SA1250 & & $311+129$ & B & Gr2 \\
\hline \multirow[t]{2}{*}{ GOLGA2LY Genes } & GOLY/I & SA768 & Hhal & 531 & $A$ & 1 copy \\
\hline & & SA769 & & $289+242$ & $\mathrm{~B}$ & 1 copy \\
\hline \multirow[t]{2}{*}{ BPY2 Genes } & $\mathrm{BPY} 2 / \mathrm{I}$ & SA766 & ECORV & 470 & A & 2 copies \\
\hline & & SA767 & & $289+181$ & $\mathrm{~B}$ & I copy \\
\hline \multirow[t]{2}{*}{ TTY4 Genes } & TTY4/I & SA764 & Haelll & 541 & A & 1 copy \\
\hline & & SA765 & & $323+218$ & B & 2 copies \\
\hline
\end{tabular}

and dimethylarsinous acid (DMA) are produced in mammals [37]. It was long believed that the methylation steps constitute a yet to be elucidated detoxification process. However, the fact that bacteria and fungi can successfully survive arsenic exposure and demethylate the arsenic suggests that the methylation is an effect of arsenic $[38,39]$. Further, mice have been found to be highly resistant to arsenic toxicity. Though $\mathrm{C} 3 \mathrm{H}$ and CD1 mice show increased liver tumor incidence exposed to drinking water arsenic [40-43], it has yet to be confirmed. This is because subsequent experiments on C3 $\mathrm{H}$ mice by Ahlborn et al 2009 [44] reported a significant reduction in tumor occurrence $(0 \%)$ and also that the arsenic exposure given was far exceeding the limit (85 $\mathrm{ppm}$ ) what humans were exposed to. Assessment of arsenic on the human Y chromosome was undertaken to uncover its possible effect.

In our study, none of the exposed samples showed any of the established recombination/deletion events of the human Y chromosome except a few random microdeletions. In our earlier reports in males exposed to natural background radiation showed a similar pattern but the occurrence of genetical changes was at a higher frequency [36]. In our study, deletion was restricted to provirus B region (see figure 2) which is due to the presence of short stretches of homologous sequences [36]. These changes 
Table 3 Comparative analysis of SNVs located in the AZFc amplicons between the exposed and unexposed males.

\begin{tabular}{|c|c|c|c|}
\hline$\overline{\text { SNV }}$ & PROFILE & $\begin{array}{c}\% \text { OF EXPOSED } \\
\text { MALES }\end{array}$ & $\begin{array}{c}\% \text { OF UNEXPOSED } \\
\text { MALES }\end{array}$ \\
\hline \multirow[t]{3}{*}{ b2_AZFC_SFV } & $A+B$ & 100 & 100 \\
\hline & $A$ & 0.0 & 0.0 \\
\hline & B & 0.0 & 0.0 \\
\hline \multirow[t]{3}{*}{ b3_AZFC_SFV } & $A+B$ & 67.6 & 88.2 \\
\hline & B & 29.4 & 11.8 \\
\hline & A & 2.9 & 0.0 \\
\hline \multirow[t]{3}{*}{ b4_AZFC_SFV } & $A+B$ & 83.3 & 91.7 \\
\hline & $A$ & 16.7 & 8.3 \\
\hline & $B$ & 0.0 & 0.0 \\
\hline \multirow[t]{3}{*}{ g1_AZFC_SFV } & $A+B$ & 83.3 & 93.8 \\
\hline & $\mathrm{A}$ & 14.6 & 6.2 \\
\hline & B & 2.1 & 0.0 \\
\hline \multirow[t]{3}{*}{ g2_AZFC_SFV } & $A+B$ & 91.2 & 100 \\
\hline & A & 5.9 & 0.0 \\
\hline & B & 2.9 & 0.0 \\
\hline \multirow[t]{3}{*}{ g3_AZFC_SFV } & $A+B$ & 87.5 & 91.6 \\
\hline & A & 6.25 & 4.2 \\
\hline & $B$ & 6.25 & 4.2 \\
\hline \multirow[t]{3}{*}{ g_AZFC_SFV } & $A+B$ & 88.9 & 100 \\
\hline & A & 0.0 & 0.0 \\
\hline & B & 11.1 & 0.0 \\
\hline
\end{tabular}

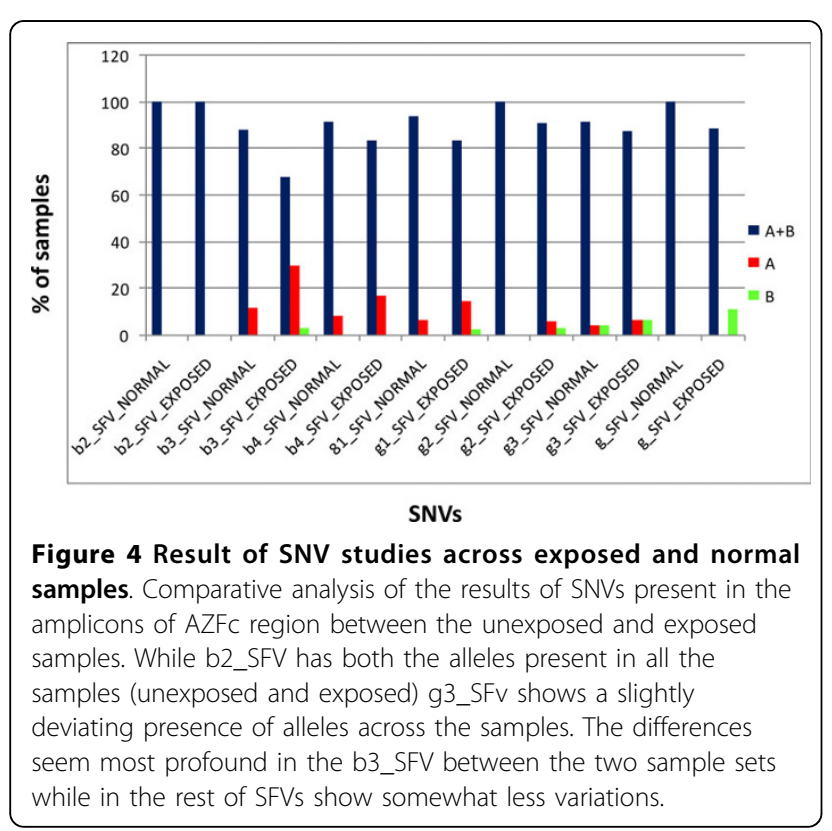

Table 4 Results summary of SNVs analyzed in the genes in AZFc region with one sample (2k44) showed DAZ4 deletion haplotype.

\begin{tabular}{ccc}
\hline Gene & Allele A only & Allele B only \\
\hline TTY4 & - & $2 k 27,2 k 28,2 k 34,2 k 42,2 k 45$ \\
\hline BPY2 & $2 k 12,2 k 27,2 k 28,2 k 35,2 k 38$ & $1 k 4$ \\
\hline GOLGA2LY & $2 k 39,2 k 40,1 k 3,1 k 4$ & $2 k 44,1 k 1,1 k 8$ \\
\hline DAZ SNV I & $2 \mathrm{~K} 10,2 \mathrm{k} 18,2 \mathrm{k} 23,2 \mathrm{~K} 44$ & - \\
\hline DAZ SNV III & $2 \mathrm{~K} 16,2 \mathrm{~K} 17$ & $2 \mathrm{~K} 46,2 \mathrm{~K} 47$ \\
\hline DAZ SNV VI & $2 \mathrm{~K} 44$ & - \\
\hline
\end{tabular}

Table 5 The primers designed for end point PCR analysis of DYZ1 repeat region.

\begin{tabular}{|c|c|c|c|c|}
\hline Primer & Sequence & Location & Orientation & $\begin{array}{c}\mathrm{Tm}\left({ }^{\circ}\right. \\
\mathrm{C})\end{array}$ \\
\hline$\underline{\text { DYZ1A }}$ & TTTCCTTTCGCTTGCATTCCAT & $25-47$ & $5^{\prime}-3^{\prime}$ & 65 \\
\hline DYZ1B & TTTGAGTCCGTTCCATAACAC & $\begin{array}{l}1347- \\
1367 \\
\end{array}$ & $5^{\prime}-3^{\prime}$ & 64 \\
\hline DYZ1C & GAGTCCATTCACTTCCAGAACA & $\begin{array}{l}3128- \\
3149\end{array}$ & $5^{\prime}-3^{\prime}$ & 63 \\
\hline DYZ1D & CCATGCCATITTATTGCGTTGC & $\begin{array}{l}1791- \\
1821\end{array}$ & $5^{\prime}-3^{\prime}$ & 63 \\
\hline DYZ1E & GACTGGAAAGGCTGGGTGTCGA & $\begin{array}{l}3380- \\
3402 \\
\end{array}$ & $3^{\prime}-5^{\prime}$ & 63 \\
\hline DYZ1F & TGAAATGGACTGGAAAGGAATG & $268-290$ & $3^{\prime}-5^{\prime}$ & 64 \\
\hline$\overline{D Y Z 1 G}$ & TGGAATGGACTGCAATAGAAAG & $\begin{array}{l}1566- \\
1588 \\
\end{array}$ & $3^{\prime}-5^{\prime}$ & 64 \\
\hline DYZ1H & TGGAATGGACTCGAACAGAGTG & $\begin{array}{l}2097- \\
2119\end{array}$ & $3^{\prime}-5^{\prime}$ & 64 \\
\hline
\end{tabular}

are attributed to the effect of arsenic exposure since the unexposed samples lack such deletions.

Arsenic has been known to cause deletions in cell lines but in the absence of animal models, it is impossible to undertake an in-vivo study. Even in the cell lines, several anomalies were reported but their mechanism

Table 6 The primer combinations from table 3 used for PCR of DYZ1 array and expected amplicons

\begin{tabular}{ccc}
\hline SI no & Combination & Amplicon (bp) \\
\hline 1 & DYZ1A \& DYZ1E & 3378 \\
\hline 2 & DYZ1A \& DYZ1F & 266 \\
\hline 3 & DYZ1A \& DYZ1G & 1564 \\
\hline 4 & DYZ1A \& DYZ1H & 2095 \\
\hline 5 & DYZ1B \& DYZ1E & 2056 \\
\hline 6 & DYZ1B \& DYZ1G & 242 \\
\hline 7 & DYZ1B \& DYZ1H & 773 \\
\hline 8 & DYZ1C \& DYZ1E & 275 \\
\hline 9 & DYZ1 D \& DYZ1E & 1612 \\
\hline 10 & DYZ1 D \& DYZ1H & 329
\end{tabular}




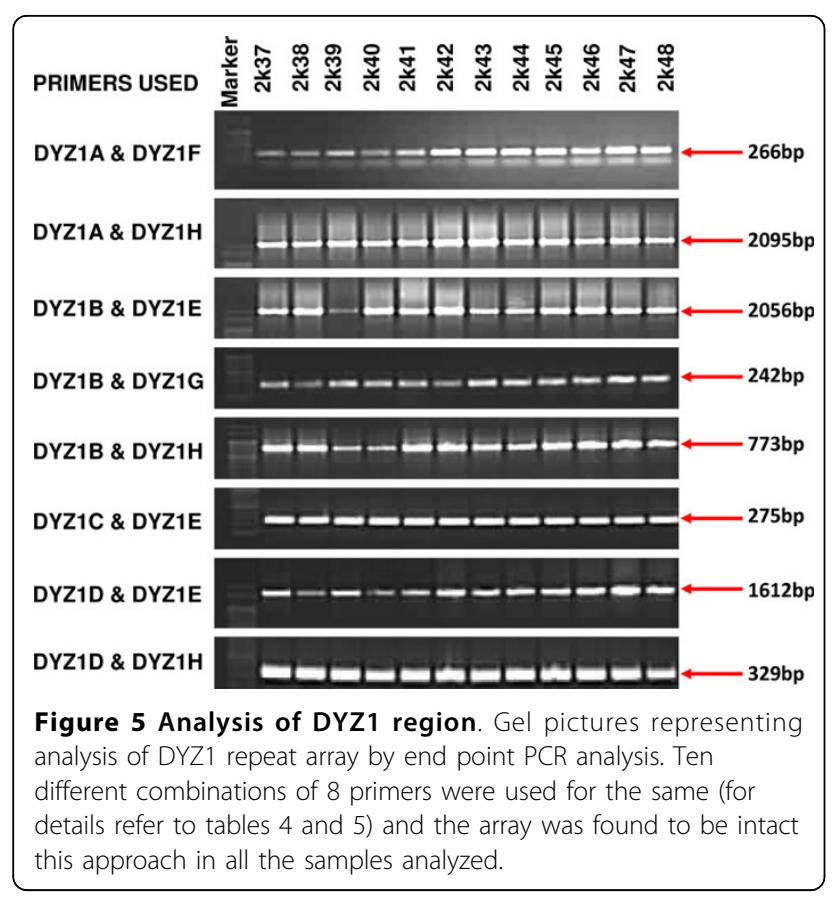

remains to be elucidated. On what basis arsenic chooses genetic targets are yet to be uncovered and any specific preference for a particular chromosome or sequence is being probed at. There are multiple reports establishing the involvement of arsenic in sister chromatid exchange (SCE) and chromosomal aberrations in cultured cells [45-47]. None of these or subsequent reports have focussed on the Y chromosome. However, it may be noted that the human $\mathrm{Y}$ chromosome contains sizable part of palindromic and repeat sequences which makes it susceptible to chromosomal rearrangements, deletions and recombination. In view of the ability of arsenic to induce such aberrations, $\mathrm{Y}$ chromosome provides an ideal setting for such study. We further plan to study the integrity of $\mathrm{Y}$ chromosome in cell lines when exposed to arsenic.

The possible role of $\mathrm{Y}$ haplogroups also needs to be accounted for prior to any conclusions. In present study, samples were collected from northern India belonging to Indo-European origins which predominantly contains $R$ haplogroup with variations in the DYS marker series $[48,49]$. Due to the expected

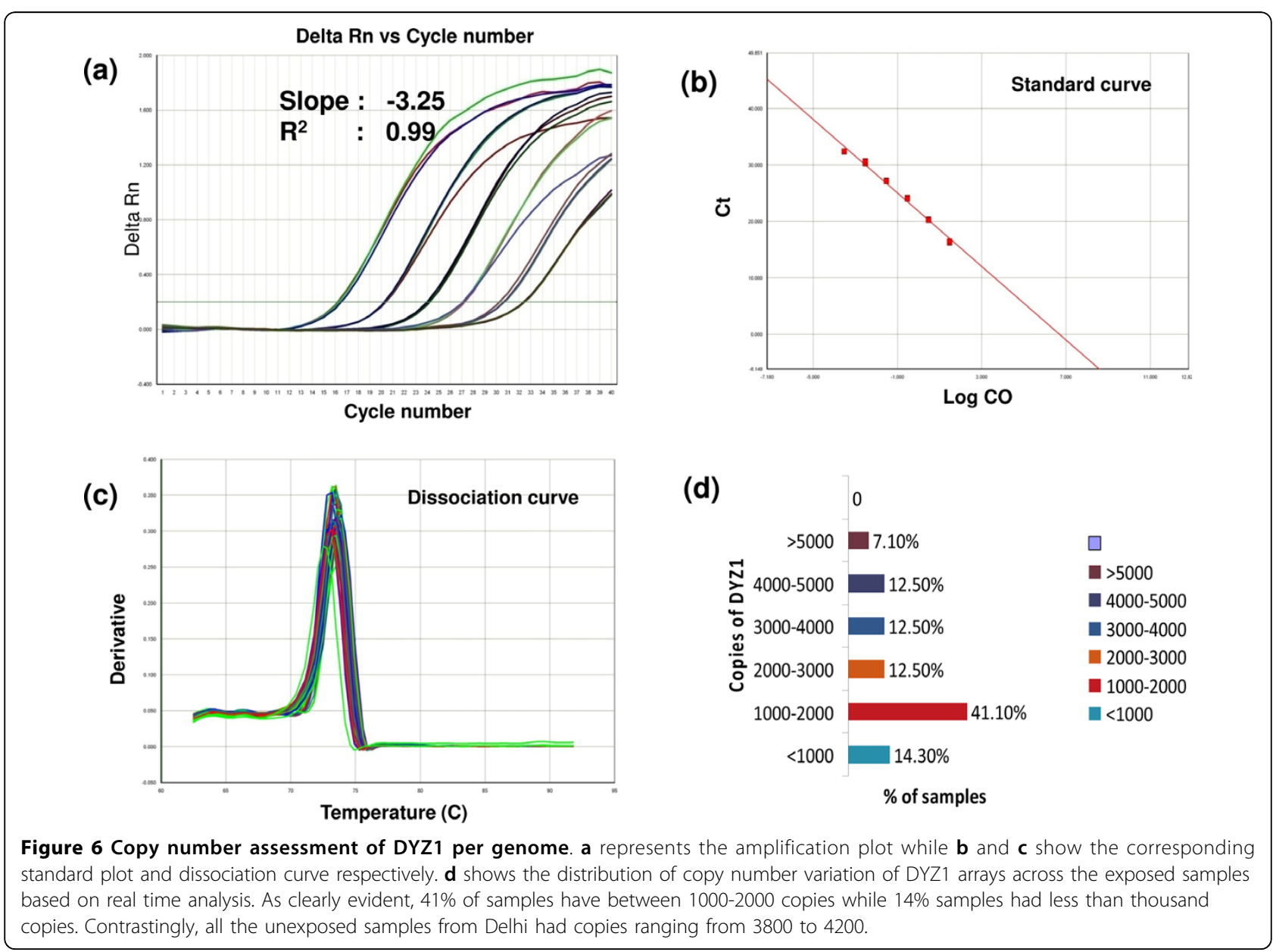



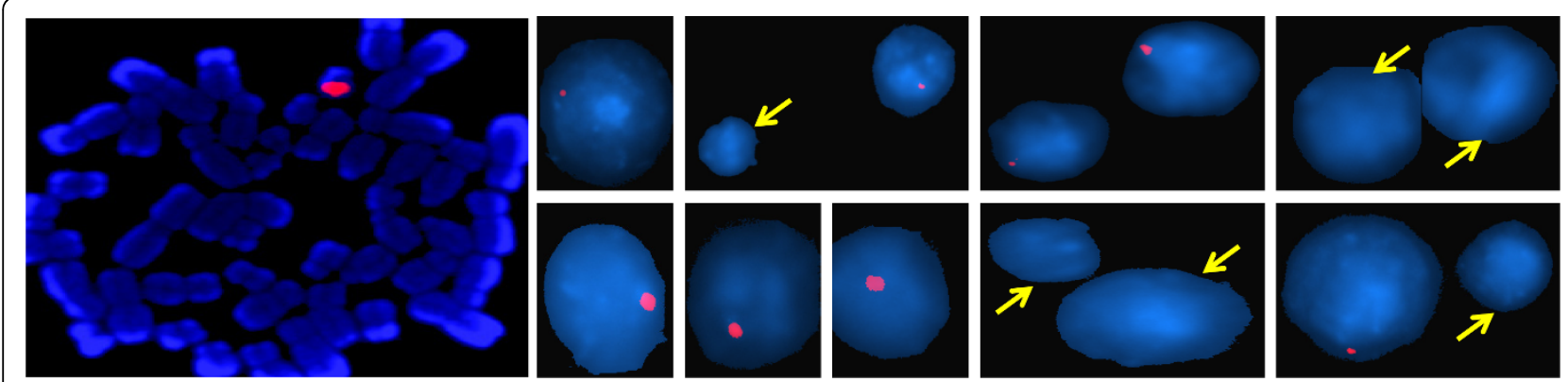

Figure 7 FISH analysis of DYZ1 array. The metaphase and interphase nuclei stained with DAPI showing DYZ1 probe signal. Note the variation in intensities across nuclei and absence of signals in some which has been highlighted by arrows.

uniform distribution of this haplogroup in control and affected sampling regions, we believe deviations between the two sample-groups cannot be significantly attributed to haplogroups. We hypothesize that arsenic in the human body behaves distinctly different as compared to that in established cell lines. Perhaps human body is lot more efficient to counteract the adverse effects of arsenic compared to an individual cell or established cell lines.

SNV analysis showed only one sample with DAZ 4 del haplotype which seems to be a random occurrence and the results of ampliconic SNVs seem to be biased. Of the 7 SNVs in the amplicons of AZFc region, only one located in b2 amplicon showed identical pattern of SNV in normal and exposed samples. The other 6 SNVs showed variation across the sample sets with maximum one in b3 amplicon (figure 4 and table 3).

Most startling aspect of our study was the data on the DYZ1 repeat array. Though the PCR analysis by primers along its length presented a normal picture in all the samples, real time and FISH data were found to be more revealing. The number of copies present in samples varied from $672(2 \mathrm{k} 48)$ to $8576(2 \mathrm{k} 21)$ with an astounding $55 \%$ samples having less than 2000 copies per genome (Figure 6d). The unexposed samples on the other hand also showed arrays copy number variation but in much smaller range. Further, variation in signal intensity within the cell population of same individual after FISH and absence of signal in $\sim 20 \%$ cells in 19 samples seems to be an indicative of the arsenic effects on DYZ1 array. The selective absence of signals from certain percentage of cells might be indicative of arsenic induced aneuploidy. In this context, chromosomal analysis at the sequence and mapping level is required to resolve this issue. Interestingly, the samples which were showing arsenic skin lesions did not show any apparent bias towards the aberrations whatsoever. This highlights our sparingly inconsequent understanding of arsenic in the human body.

\section{Conclusions}

We conclude that arsenic is indeed affecting the human $\mathrm{Y}$ chromosome at a low level and apparently repeat regions are more prone as evident from our DYZ1 study. Though present study is surely an indicative of some arsenic manifestations in the body, a large scale screening of the exposed samples at the genetic level is required to substantiate the effects of arsenic exposure on the human system. The potential role of repeat regions being involved in arsenic induced carcinogenesis can further be investigated. Absence of a reliable animal model would continue to dodge the efforts on this line but sustained efforts would surely yield the mysteries behind action of arsenic on human body.

\section{Abbreviations}

AZF: Azoospermia Factor; BPY: Basic charge, Y-linked; DAZ: Deleted in Azoospermia; DDX3Y: DEAD (Asp-Glu-Ala-Asp) box polypeptide 3, Y-linked; DMA: Dimethylarsinous Acid; FISH: Fluorescence In Situ Hybridization; GOLGA2LY: Golgi- antigene 2-like Y; MMA: Monomethylarsanous Acid; MNU: $\mathrm{N}$-methyl-N-nitrosourea; RBMY: RNA-binding motif gene on Y chromosome: SCE: Sister Chromatid Exchange; SFV: Sequence Family Variants; SNV: Single Nucleotide Variant; STS: Sequence Tagged Site; TSPY: Testis-Specific Protein Y encoded; TY4: Testes Transcript Y 4; WHO: World Health Organization.

\section{Acknowledgements}

This work was supported by DBT Grant No. BT/PR8476/AAQ/01/315/2006 and BT/PR1 1805/MED/12/424/2009 to SA and a core grant from Department of Biotechnology, Government of India to National Institute of Immunology, New Delhi. We thank Alexander Von Humboldt Foundation, Bonn, Germany for Equipment donation, Mohammad Yusuf Afaque for sample collection without which this study won't have been feasible and Shri Khem Singh Negi for technical assistance. This work was seen and approved by all the authors and they do not have any conflict of personal communication or financial interests.

\section{Authors' contributions}

Safdar A: carried out the studies and drafted the manuscript. Sher A: conceived of the study, participated in its design and coordination and helped to draft the manuscript. Both authors read and approved the final manuscript.

\section{Competing interests}

The authors declare that they have no competing interests.

Received: 8 February 2010 Accepted: 6 August 2010

Published: 6 August 2010 


\section{References}

1. Pearce F: Arsenic in the water. The Guardian (UK) 1998, 19/25:2-3.

2. Guidelines for Drinking Water Quality, 2nd ed., vol. 2, Health Criteria and other Supporting Information. WHO, Geneva 1996, 940-949.

3. Smith AH, Hopenhayn-Rich C, Bates MN, Goeden HM, Hertz-Picciotto I, Duggan HM, Wood R, Kosnett MJ, Smith MT: Cancer risks from arsenic in drinking water. Environmet Health Perspectives 1992, 97:259-267.

4. National Research Council: Arsenic in Drinking Water: 2001 Update. National Academy Press, Washington, D. C 2001, 217-225.

5. Rahman M, Vahter M, Wahed MA, Sohel N, Yunus M, Streatfield PK, El Arifeen S, Bhuiya A, Zaman K, Chowdhury AMR, Ekstrom E, Persson LA: Prevalence of arsenic exposure and skin lesions. A population based survey in Matlab, Bangladesh. J Epidemiol Community Health 2006, 60:242-248.

6. Barrett JC, Lamb PW, Wang TC, Lee TC: Mechanisms of arsenic-induced cell transformation. Biol Trace Elem Res 1989, 21:421-9.

7. Lee T, Oshimura M, Barrett JC: Comparison of arsenic-induced cell transformation, cytotoxicity, mutation and cytogenetic effects in Syrian hamster embryo cells in culture. Carcinogenesis 1985, 6:1421-142.

8. Nakamuro K, Sayato $Y$ : Comparative studies of chromosomal aberration induced by trivalent and pentavalent arsenic. Mutat Res 1981, 88:73-80.

9. Gonsebatt ME, Vega L, Salazar AM, Montero R, Guzmán P, Blas J, Del Razo LM, García-Vargas G, Albores A, Cebrián ME, Kelsh M, OstroskyWegman P: Cytogenetic effects in human exposure to arsenic. Mutat Res 1997, 386:219-28.

10. Liu SX, Athar M, Lippai I, Waldren C, Hei TK: Induction of oxyradicals by arsenic: Implication for mechanism of genotoxicity. PNAS 2001, 98:1643-1648.

11. Cavigelli M, Li WW, Lin A, Su B, Yoshioka K, Karin M: The tumor promoter arsenite stimulates AP-1 activity by inhibiting a JNK phosphatase. EMBO J 1996, 15:6269-79.

12. Rossman TG: Mechanism of arsenic carcinogenesis: an integrated approach. Mutat Res 2003, 533:37-65.

13. Wang Z, Rossman TG: The carcinogenicity of arsenic, in: I.W Chang (Ed.), Toxicology of Metals. CRS Press, Boca Raton 1996, 219-227.

14. Hsieh F, Hwang T, Hsieh Y, Lo H, Su C, Hsu H, Chiou H, Chen C: Risk of Erectile Dysfunction Induced by Arsenic Exposure through Well Water Consumption in Taiwan. Environ Health Perspect 2008, 116:532-536.

15. Samanta G, Das D, Mandal BK, Chowdhury TR, Chakraborti D, Pal A, Ahamed S: Arsenic in the breast milk of lactating women in arsenicaffected areas of West Bengal, India and its effect on infants. J Environ Sci Health A Tox Hazard Subst Environ Eng 2007, 42:1815-25.

16. Waalkes MP, Liu J, Diwan BA: Transplacental arsenic carcinogenesis in mice. Toxicol Appl Pharmacol 2007, 222:271-280.

17. Chowdhury UK, Biswas BK, Chowdhury TR, Samanta G, Mandal BK, Basu GC, Chanda CR, Lodh D, Saha KC, Mukherjee SK, Roy S, Kabir S, Quamruzzaman Q, Chakraborti D: Groundwater Arsenic Contamination in Bangladesh and West Bengal, India. Environ Health Perspect 2000, 108:393-397.

18. Ali S, Muller CR, Epplen JT: DNA fingerprinting by oligonucleotides probes specific for simple repeats. Hum Genet 1986, 74:239-243.

19. Premi S, Srivastava J, Chandy SP, Ali S: AZFc somatic microdeletions and copy number polymorphism of the DAZ genes in human males exposed to natural background radiation. Human Genet 2007, 121:337-346.

20. Bashamboo A, Rahman MM, Prasad A, Sebastian PC, Ahmad J, Ali S: Fate of SRY, PABY, DYS1, DYZ3 and DYZ1 loci in Indian patients harbouring sex chromosomal anomalies. Mol Hum Reprod 2005, 11:117-127.

21. Repping $S$, Skaletsky $H$, Lange J, Silber $S$, Van Der Veen F, Oates RD, Page DC, Rozen S: Recombination between palindromes P5 and P1 on the human $Y$ chromosome causes massive deletions and spermatogenic failure. Am J Hum Genet 2002, 71:906-922

22. Repping S, Skaletsky H, Brown L, van Daalen SK, Korver CM, Pyntikova T, Kuroda-Kawaguchi T, de Vries JWA, Oates RD, Silber S, van der Veen F, Page DC, Rozen S: Polymorphism for a 1.6-Mb deletion of the human $Y$ chromosome persists through balance between recurrent mutation and haploid selection. Nat Genet 2003, 35:247-251.

23. Repping S, van Daalen SK, Korver CM, Brown LG, Marszalek JD, Gianotten J, Oates RD, Silber S, van der Veen F, Page DC, Rozen S: A family of human Y chromosomes has dispersed throughout northern Eurasia despite a 1.8-
$\mathrm{Mb}$ deletion in the azoospermia factor c region. Genomics 2004, 83:1046-1052.

24. Kuroda-Kawaguchi T, Skaletsky H, Brown LG, Minx PJ, Cordum HS, Waterson RH, Wilson RK, Silber S, Oates R, Rozen S, Page DC: The AZFC region of the $Y$ chromosome features massive palindromes and uniform recurrent deletions in infertile men. Nat Genet 2001, 29:279-286.

25. Fernandes S, Parachchini S, Meyer LH, Florida G, Tyler-Smith C, Vogt PH: A large AZFc deletion removes DAZ3/DAZ4 and nearby genes from men in Y haplogroup N. Am J Hum Genet 2004, 74:180-187.

26. Ferlin A, Moro E, Rossi A, Dallapiccola B, Foresta C: The human $Y$ chromosome's azoospermia factor b (AZFb) region: sequence, structure, and deletion analysis in infertile men. J Med Genet 2003, 40:18-24.

27. Sun C, Skaletsky H, Rozen S, Gromoll J, Nieschlag E, Oates R, Page DC: Deletion of the azoospermia factor a (AZFa) region of human $Y$ chromosome caused by recombination between HERV15 proviruses. Hum Mol Genet 9:2291-2296.

28. Kamp C, Hirschmann P, Voss H, Huellen K, Vogt PH: Two long homologous retroviral sequence blocks in proximal Yq11 cause AZFa microdeletions as a result of intrachromosomal recombination events. Hum Mol Genet 2000, 9:2563-2572

29. Blanco P, Shlumukova M, Sargent CA, Jobling MA, Affara N, Hurles ME: Divergent outcomes of intrachromosomal recombination on the human Y chromosome: male infertility and recurrent polymorphism. J Med Genet 2000, 37:752-758.

30. Jobling MA, Lo IC, Turner DJ, Bowden GR, Lee AC, Xue Y, Carvalho-Silva D, Hurles ME, Adams SM, Chang YM, Kraaijenbrink T, Henke J, Guanti G, McKeown B, Oorschot RAH, Mitchell RJ, de Knijff P, Tyler-Smith C, Parkin EJ: Structural variation on the short arm of the human $Y$ chromosome: recurrent multigene deletions encompassing Amelogenin Y. Hum Mol Genet 2007, 16:307-316

31. Fernandes S, Huellen K, Goncalves J, Dukal H, Zeisler J, Rajpert De Meyts E, Skakkebaek NE, Habermann B, Krause W, Sousa M, Barros A, Vogt PH: High frequency of DAZ1/DAZ2 gene deletions in patients with severe oligospermia. Mol Hum Reprod 2002, 8:286-298.

32. Saxena R, De Vries JWA, Repping S, Algappan R, Skaletsky H: Four DAZ genes in two clusters found in AZFc region of the human $Y$ chromosome. Genomics 2000, 67:256-267.

33. Navarro-Costa P, Pereira L, Alves C, Gusmão L, Proença C, Marques-Vidal P, Rocha T, Correia SC, Jorge S, Neves A, Soares AP, Nunes J, Calhaz-Jorge C, Amorim A, Plancha CE, Gonçalves J: Characterizing partial AZFc deletions of the $\mathrm{Y}$ chromosome with amplicon-specific sequence markers. BMC Genomics 2007, 8:342.

34. Nakahori $Y$, Mitani $K$, Yamada M, Nakagome $Y$ : A human $Y$-chromosome specific repeated DNA family (DYZ1) consists of a tandem array of pentanuceotides. Nucleic Acids Research 1986, 14:7569-7580.

35. Jehan Z, Vallinayagam S, Tiwari S, Pradhan S, Singh L, Suresh L, Reddy HM, Jesudasan RA: Novel noncoding RNA from human $Y$ distal heterochromatic block (Yq12) generates testis-specific chimeric CDC2L2. Genome Res 2007, 17:433-440.

36. Premi S, Srivastava J, Chandy SP, Ali S: Unique Signatures of Natural Background Radiation on Human Y Chromosomes from Kerala, India. Plos One 2009.

37. Aposhian HV, Arroyo A, Cebrian ME, del Razo LM, Hurlbut KM, Dart RC, Gonzalez-Ramirez D, Kreppel H, Speisky H, Smith A, Gonsebatt ME, OstroskyWegman P, Aposhian MM: DMPS-arsenic challenge test. I. Increased urinary excretion of monomethylarsonic acid in humans given dimercaptopropane sulfonate. J Pharmacol Exp Ther 1997, 282:192-200.

38. Yamamoto S, Konishi Y, Matsuda T, Murai T, Shibata MA, Matsui-Yuasa I, Otani S, Kuroda K, Endo G, Fukushima S: Cancer induction by an organic arsenic compound, dimethylarsinic acid (cacodylic acid), in F344/DuCrj rats after pretreatment with five carcinogens. Cancer Res 1995, 55:1271-1276.

39. Sampayo-Reyes A, Zakharyan RA, Healy SM, Aposhian HV: Monomethylarsonic acid reductase and monomethylarsonous acid in hamster tissue. Chem Res Toxicol 2000, 13:1181-1186.

40. Waalkes MP, Ward JM, Liu J, Diwan BA: Transplacental carcinogenicity of inorganic arsenic in the drinking water: induction of hepatic, ovarian, pulmonary, and adrenal tumors in mice. Toxicol Appl Pharmacol 2003, 186:7-17. 
41. Waalkes MP, Liu J, Ward JM, Diwan BA: Animal models for arsenic carcinogenesis: inorganic arsenic is a transplacental carcinogen in mice. Toxicol Appl Pharmacol 2004, 198:377-384.

42. Waalkes MP, Ward JM, Diwan BA: Induction of tumors of the liver, lung, ovary and adrenal in adult mice after brief maternal gestational exposure to inorganic arsenic: promotional effects of postnatal phorbol ester exposure on hepatic and pulmonary, but not dermal cancers. Carcinogenesis 2004, 35:133-141.

43. Waalkes MP, Liu J, Ward JM, Powell DA, Diwan BA: Urogenital carcinogenesis in female CD1 mice induced by in utero arsenic exposure is exacerbated by postnatal diethylstilbestrol treatment. Cancer Res 2006, 66:1337-1345.

44. Ahlborn GJ, Nelson GM, Grindstaff RD, Waalkes MP, Diwan BA, Allen JW, Kitchin KT, Preston J, Thomas DJ, Delker DA: Impact of life stage and duration of exposure on arsenic-induced proliferative lesions and neoplasia in C3 H mice. Toxicology 2009, 262:106-113.

45. Eastmond $D$, Tucker J: Identification of aneuploidy-inducing agents using cytokinesis-blocked human lymphocytes and an antikinetochore antibody. Environ Mol Mutagen 1989, 13:34-43.

46. Jha AN, Noditi M, Nilsson R, Natarajan AT: Genotoxic effects of sodium arsenite on human cells. Mutation Res 1992, 248:215-221.

47. Vega L, Gonsebatt ME, Ostrosky-Wegman P: Aneugenic effect of sodium arsenite on human lymphocytes in vitro: an individual susceptibility effect detected. Mutation Res 1995, 334:365-373.

48. Sengupta S, Zhivotovsky LA, King R, Mehdl SQ, Edmonds CA, Chow CT, Lin AA, Mitra M, Sil SK, Ramesh A, Rani MVU, Thakur CM, Cavalli-Sforza LL, Majumder PP, Underhill PA: Polarity and Temporality of High-Resolution Y-Chromosome Distributionsin India Identify Both Indigenous and Exogenous Expansions and Reveal Minor Genetic Influence of Central Asian Pastoralists. Am J of Hum Genet 2006, 78:202-221.

49. World Haplogroup Maps. [http://www.scs.uiuc.edu/ mcdonald/ WorldHaplogroupsMaps.pdf].

\section{Pre-publication history}

The pre-publication history for this paper can be accessed here: http://www.biomedcentral.com/1755-8794/3/35/prepub

doi:10.1186/1755-8794-3-35

Cite this article as: Ali and Ali: Genetic integrity of the human $Y$ chromosome exposed to groundwater arsenic. BMC Medical Genomics 2010 3:35.

\section{Submit your next manuscript to BioMed Central and take full advantage of:}

- Convenient online submission

- Thorough peer review

- No space constraints or color figure charges

- Immediate publication on acceptance

- Inclusion in PubMed, CAS, Scopus and Google Scholar

- Research which is freely available for redistribution 